\title{
PARTHENOLIDE: SUGGESTED DRUG FOR COVID-19
}

\author{
M. Nemati, F. Danesh Pouya, E. Roshni Asl, Y. Rasmi \\ Urmia University of Medical Sciences, Urmia, Iran
}

\begin{abstract}
Severe acute respiratory syndrome coronavirus 2 (SARS-CoV-2) is the 2019 novel coronavirus (2019-nCoV) that causes acute respiratory distress syndrome (ARDS) which is the main reason for patients mortality. One of the effective treatments to reduce the effects of this virus is parthenolide (PN). Parthenolide is a sesquiterpene lactone found in medicinal plants. It can inhibit several pro-inflammatory signaling pathways, in particular the ATPase activity of NLRP3. Based on its ability to suppress inflammatory signal transduction and elevated level of serum IL-1 $\beta$ (a surrogate marker for NLRP3 activation) in COVID-19 patients, we suggest that PN could be potentiallyeffective for the treatment of COVID-19.
\end{abstract}

Key words: Parthenolide, COVID-19, $N F-\kappa B$.

\section{ПАРТЕНОЛИД: ВОЗМОЖНОЕ ЛЕКАРСТВО ОТ COVID-19}

Немати М., Данеш Пойа Ф., Рохни Асл Е., Расми Ю.

Урмийский университет медицинских наук, Урмия, Иран

Резюме. Новый коронавирус тяжелого острого респираторного синдрома (SARS-CoV-2) вызывает развитие респираторного дистресс-синдрома, являющегося основной причиной смерти пациентов. Одним из эффективных методов снижения воздействия этого вируса является партенолид (PN). Партенолид - сесквитерпеновый лактон, содержащийся в лекарственных растениях, способный подавлять ряд провоспалительных сигнальных каскадов, в частности АТФ-азную активность инфламмасомы NLRP3. Учитывая его способность блокировать проведение воспалительных сигналов и повышенный уровень сывороточного цитокина IL-1 $\beta$ (как суррогатного маркера активации NLRP3) у пациентов с COVID-19, мы полагаем, что Партенолид мог бы быть эффективен при лечении COVID-19.

Ключевые слова: Партенолид, COVID-19, NF-кB.

Severe acute respiratory syndrome coronavirus 2 (SARS-CoV-2), or the 2019 novel coronavirus (2019-nCoV), is rapidly spreading from Wuhan, Hubei Province, China, to the rest of the world [11]. Respiratory failure from acute respiratory distress syndrome (ARDS) is the prominent reason for mortality [9]; so, there is a critical need for effective treatment. The P21-activated kinase (PAK1, RAC/ CDC42-activated kinase 1) is the main "pathogenic" kinase. The abnormal activation of PAK1 takes place due to different diseases/disorders such as inflamma- tion, malaria, and pandemic viral infection such as influenza and COVID-19 [8]. In the PAK1 signaling pathway, after activation of the epidermal growth factor receptor (EGFR) by epidermal growth factor (EGF), then RAS (guanosine-nucleotide-binding protein) activates; following that, PAK1 stimulates inflammatory pathways by nuclear factor kappa B $(\mathrm{NF}-\kappa \mathrm{B})$ activation [4]. The $\mathrm{NF}-\kappa \mathrm{B}$ controls the expression of genes encoding the chemokines (e.g., IL-8), pro-inflammatory cytokines (e.g., IL-1, IL-2, IL-6 and TNF $\alpha$ ), inducible enzymes (e.g., cyclooxy-

\author{
Адрес для переписки: \\ Юсеф Расми \\ Иран, Урмия, Урмийский университет медицинских наук. \\ Тел.: +989143174740. Факс: +984432780801. \\ E-mail: rasmiy@umsu.ac.ir

\section{Библиографическое описание:} \\ Немати М., Данеш Пойа Ф., Рохни Асл Е., Расми Ю. Партенолид: \\ возможное лекарство от COVID-19 // Инфекция и иммунитет. 2020. T. 10, \\ № 4. C. 789-791. doi: 10.15789/2220-7619-PSD-1509
}

\section{Contacts:}

Yousef Rasmi

Iran, Urmia, Urmia University of Medical Sciences.

Phone: +989143174740. Fax: +984432780801.

E-mail: rasmiy@umsu.ac.ir

\section{Citation:}

Nemati M., Danesh Pouya F., Roshni Asl E., Rasmi Y. Parthenolide: suggested drug for COVID-19 // Russian Journal of Infection and Immunity = Infektsiya i immunitet, 2020, vol. 10, no. 4, pp. 789-791. doi: 10.15789/22207619-PSD-1509

DOI: http://dx.doi.org/10.15789/2220-7619-PSD-1509 


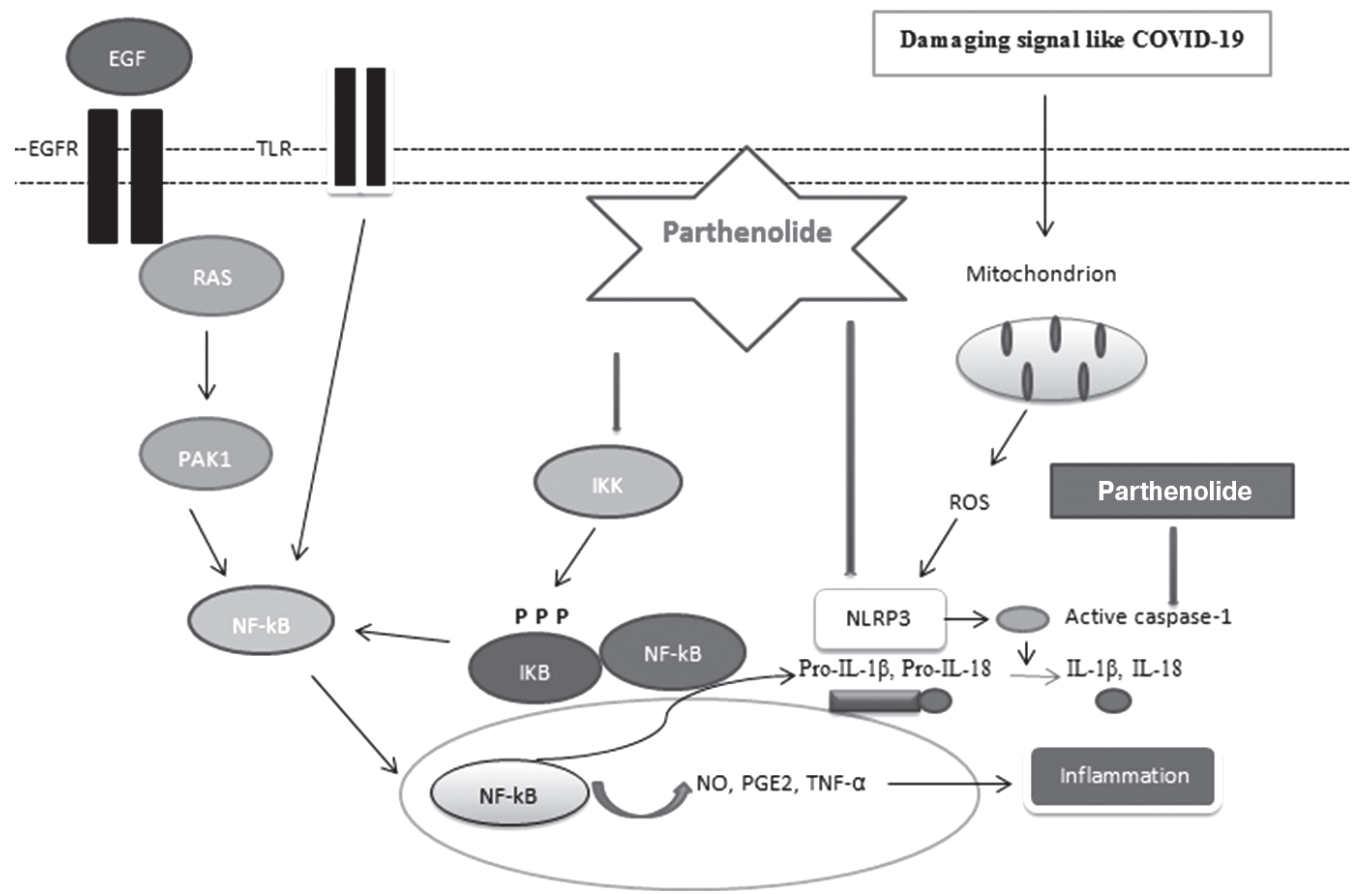

Figure. Anti-inflammatory effect of Parthenolide on COVID-19

EGF - Epidermal growth factor; EGFR - Epidermal growth factor receptor; PAK1 - P21 activated kinase 1; NF- $\mathrm{KB}$ - Nuclear factor kappa B; NO - Nitric oxide; PGE2 - Prostaglandin E2; TNF $\alpha$ - Tumor necrosis factor-alpha; IL-1 $\beta$ - Interleukin-1 $\beta$; IL-18 - Interleukin-18; TLR - Toll-like receptor; ROS - Reactive oxygen species; IKK — IKB kinase; IKB - inhibitory protein of NF-kB complex; NLRP3 - NLR family pyrin domain containing 3.

genase-2 (COX-2) and inducible nitric oxide synthase (iNOS)), adhesion molecules (e.g., intracellular adhesion molecule (ICAM) and, E-selectin), growth factors, some of the acute phase proteins, and immune receptors, all of these factors play critical roles in controlling most inflammatory process [1]. One of the effective treatments to reduce the effects of this signaling pathway is parthenolide (PN). Parthenolide is a sesquiterpene lactone found in medicinal plants, particularly in feverfew (Tanacetum parthenium) [10]. Parthenolide has anti-inflammatory actions through the inhibition of several pro-inflammatory signaling pathways, including nitric oxide (NO), prostaglandins (PGs), leukotrienes (LTs), TNF $\alpha$, and cytokines of the IL families [1]. Studies have shown that PN is capable of inhibiting the activity of the $\mathrm{NF}-\kappa \mathrm{B}$ subunit RelA/p65 by inhibiting the I $\mathrm{B}$ (inhibitory protein of $\mathrm{NF}-\kappa \mathrm{B}$ complex) kinase-mediated phosphorylation of $\mathrm{I} \kappa \mathrm{B}$ [3], suggesting that $\mathrm{PN}$ is a novel therapeutic agent for treating COVID-19. Parthenolide also inhibits the activity of multiple inflammasomes, which produces the active pro-inflammatory cytokines IL-1 $\beta$ and IL-18 from the inactive pro-IL-1 $\beta$ and pro-IL-18, in macrophages by directly inhibiting the protease activity of caspase-1 [6]. The NLR family pyrin domain containing 3 (NALP3) inflammasome [4] is an important component of the innate immune response against a broad range of microbial signals and it is activates by diverse signals such as viruses [7]. The molecular mechanism of activation of the NLRP3 inflammasome by these diverse stimuli is still unclear, but the evidence suggests that NLRP3 is transcriptionally up-regulated by $\mathrm{NF}-\kappa \mathrm{B}$-inducing stimuli such as ligands of the Toll-like receptors [2]. Juliana et al. have shown for the first time that $\mathrm{PN}$ is an inhibitor of the ATPase activity of NLRP3 [6]. On the other hand, the investigations reported that serum IL-1 $\beta$ (a surrogate marker for NLRP3 activation) elevates in COVID-19 patients [5]. Therefore, we can suggest that PN, an anti-inflammatory agent that inhibits the NF- $\mathrm{B}, \mathrm{NLRP} 3$, and caspase 1 , is the potentially effective treatment for COVID-19 (fig.).

\section{References}

1. Abad M.J., Guerra J.A., Bermejo P., Govil J., Singh V.K., Mishra S.K. Phytochemistry and pharmacology of Tanacetum: recent developments (2008).

2. Bauernfeind F.G., Horvath G., Stutz A., Alnemri E.S., MacDonald K., Speert D., Fernandes-Alnemri T., Wu J., Monks B.G., Fitzgerald K.A., Hornung V., Latz E. Cutting edge: NF-kappaB activating pattern recognition and cytokine receptors license NLRP3 inflammasome activation by regulating NLRP3 expression. J. Immunol., 2009, vol. 183, no. 2, pp. 787-791. doi: 10.4049/ jimmunol.0901363 
3. Dai Y., Guzman M.L., Chen S., Wang L., Yeung S.K., Pei X.Y., Dent P., Jordan C.T., Grant S. The NF (Nuclear factor)-кB inhibitor parthenolide interacts with histone deacetylase inhibitors to induce MKK7/JNK1-dependent apoptosis in human acute myeloid leukaemia cells. Br. J. Haematol., 2010, vol. 151, no. 1, pp. 70-83. doi: 10.1111/j.1365-2141.2010.08319.x

4. Dammann K., Khare V., Gasche C. Tracing PAKs from GI inflammation to cancer. Gut, 2014, vol. 63, no. 7, pp. $1173-1184$. doi: 10.1136/gutjnl-2014-306768

5. Fitzgerald K.N. A few additional treatment possibilities for COVID19 (SARS Cov-2) addressing furin-like cleavage and pyroptosis (caspase-1 activation of inflammasome NLRP3). URL: https://www.drkarafitzgerald.com/2020/03/25/a-few-additional-treatment-possibilities-in-covid19-sars-cov-2-addressing-furin-like-cleavage-and-pyroptosis-caspacin-1-activation-of-inflammasomenlrp3 (10.09.2020)

6. Juliana C., Fernandes-Alnemri T., Wu J., Datta P., Solorzano L., Yu J.W., Meng R., Quong A.A., Latz E., Scott C.P., Alnemri E.S. Anti-inflammatory compounds parthenolide and Bay 11-7082 are direct inhibitors of the inflammasome. J. Biol. Chem., 2010, vol. 285, no. 13, pp. 9792-9802. doi: 10.1074/jbc.M109.082305

7. Martinon F., Mayor A., Tschopp J. The inflammasomes: guardians of the body. Annu. Rev. Immunol., 2009, vol. 27, pp. $229-265$.

8. Maruta H., He H. A mini-review for COVID-19 issue (2020). URL: http://apitherapy.com/wp-content/uploads/2020/06/Propolismelatonin-artemisinin-and-other-substances-as-PAK1-blocking-Therapy-of-Pandemic-Coronaviral-Infection-2020-Australia.pdf (20.08.2020)

9. Ruan Q., Yang K., Wang W., Jiang L., Song J. Clinical predictors of mortality due to COVID-19 based on an analysis of data of 150 patients from Wuhan, China. Intensive Care Med., 2020, vol. 46, no. 5, pp. 846-848. doi: 10.1007/s00134-020-05991-x

10. Smolinski A.T., Pestka J.J. Comparative effects of the herbal constituent parthenolide (Feverfew) on lipopolysaccharide-induced inflammatory gene expression in murine spleen and liver. J. Inflamm., 2005, no. 2: 6. doi: 10.1186/1476-9255-2-6

11. Wang C., Horby P.W., Hayden F.G., Gao G.F. A novel coronavirus outbreak of global health concern. Lancet, 2020, vol. 395, no. 10223, pp. 470-473. doi: 10.1016/S0140-6736(20)30185-9

\section{Авторы:}

Немати М., кафедра биохимии медицинского факультета Урмийского университета медицинских наук, Урмия, Иран; Данеш Пойа Ф., кафедра биохимии медицинского факультета Урмийского университета медицинских наук, Урмия, Иран; Рохни Асл Е., кафедра биохимии медицинского факультета Урмийского университета медицинских наук, Урмия, Иран; Расми Ю., кафедра биохимии медицинского факультета Урмийского университета медицинских наук, Урмия, Иран; Центр клеточных и молекулярных исследований, Университет медицинских наук Урмия, Урмия, Иран.

\section{Authors:}

Nemati M., Department of Biochemistry, School of Medicine, Urmia University of Medical Sciences, Urmia, Iran;

Danesh Pouya F., Department of Biochemistry, School of Medicine, Urmia University of Medical Sciences, Urmia, Iran;

Roshni AsI E., Department of Biochemistry, School of Medicine, Urmia University of Medical Sciences, Urmia, Iran;

Rasmi Y., Department of Biochemistry, School of Medicine, Urmia University of Medical Sciences, Urmia, Iran; Cellular and Molecular Research Center, Urmia University of Medical Sciences, Urmia, Iran. 